\title{
The Development of MOSIRI (Geometry Transformation Module) for High School Students
}

\author{
Emeralda Kislew Andhika Gianto ${ }^{1}$, Helti Lygia Mampouw ${ }^{2}$, Danang Setyadi ${ }^{3}$ \\ 1,2,3 Universitas Kristen Satya Wacana \\ Correspondence Address; emeraldakislew13@gmail.com
}

\begin{abstract}
Geometry transformation is one of the mathematics learning materials that are very closely related to everyday life but has many formulas that make it difficult for students, especially high school students to understand it. Seeing the importance of geometric transformation and difficulties experienced by students, the development of a geometry transformation module was carried out which was able to eliminate difficulties in studying and understanding the geometric transformation. This research is development research with ADDIE development modelto produce a valid, practical, and effectivemodule on geometric transformation. The module is aimed at helping high school students to understand the relevance of geometry transformation to reality and how to solve it. This module is declared valid in terms of media and material aspects with an average validity score of 3.7 (valid) for material aspects and 4 (valid) for media aspect. This module was tested on 10 ten grade high school students and is declared practical based on the indicators of the media practicality sheet. In addition, with the help of a test sheet, it can be seen that this module is able to improve learning outcomes. This can be seen from the results of a paired simple test which shows a significance value of 0,000 $(\leq 0,05)$ which means that this module is able to provide differences or improve students' learning outcomes based on the average pretest score which is 51 to 88 of theaverage posttest score. Based on the three tests, this module was declared valid, practical, and effective to be used in geometric transformation material for high school students.
\end{abstract}

Keywords: module; development; geometry transformation

\section{INTRODUCTION}

Geometry transformation is one of the important mathematics learning material to be studied because it can help students' visual and reasoning development. Therefore in this material, there are many formulas that require visualization abilities to obtain mathematical proof. The Regulation of the Ministry of Education Affairs Number 24 of 2016 concerning core competence\&basic competence states that geometry transformation is a mathematics learning material with Core Competence of analyzing and comparing transformation and composition transformation using matrices, and the basic competence of solving problems related to geometry transformation matrix (translation, reflection, dilation, and rotation). Seeing the numberof formulas that exist in geometric transformation material could cause difficulty for the students. In learning, students are more directed to memorizing formulas rather than finding the concepts of transformation geometry formulas. This is indicated by the results of the needs analysis carried out by the Researchers.

Edwards (Albab, Hartono \&Darmawijoyo, 2014) states that studying geometry transformation is able to provide opportunities for students to build and develop their spatial visualization abilities and geometrical reasoning to obtain mathematical proof abilities. Studying geometric transformations also gives students the opportunity to think critically about 
mathematical concepts, makes students think and realize that geometric transformations involve various disciplines with a contextual problem, and enable students to engage in activities that use high-level reasoning through various variations (Hollebrands, 2003).

Since the high school students are required to continue honing their thinking skills (The Regulation of the Ministry of Education AffairsNo. 41 of 2007), it is necessary to hold interesting mathematics learning so that students can better understand the material and feel attracted with what they are learning. This is supported by Ruseffendi (2005) which states that students will be more pleased with the field of mathematics studies when teaching and the teachers are interesting.

One way to create an interesting learning atmosphere is to use learning media. The use of interesting learning media and in accordance with the level of understanding and speed of thinking of students in the learning process can make students actively involved so that students find the mathematical concepts is more than just memorizing existing formulas. Marpaung (2002) states that understanding mathematics is more meaningful if it is built by students themselves and not in a forced state. This means that mathematical concepts are not given by means of memorization. It is feared that when students forget the formula, they cannot solve the mathematical problems. Learning media are able to adjust the level of understanding and speed of thinking of students which include modules (Saputra, Falahudin, \&Testiana, 2016).

Modules allow students with high-thinking skills to continue to explore and learn more information, while for students with lower to middle-thinking skills can repeat the parts that have not been understood because the module is designed to help students achieve their learning goals independently. This is supported by the results of research by Nuryana\&Elinda (2013) and Setiawan\&Wanarti R (2009) which show that the module is able to improve students' mathematics learning outcomes effectively. There is also the development of a geometry transformation module that has been carried out by Paradesa (2016) which develops visualbased geometry transformation modules and LutfiKhoirotunnafi'ah (2017) which develops geometric transformation modules based on critical activities, which show that modules can play an active role in helping students learn transformation geometry

MOSIRIor Geometry Transformation Module developed in this study is one type of module designed with an independent, intact, free of other learning media, adaptive, and easy to usecharacteristics. There is also a new thing containedin this module called MOSIRI that is able to be used to adjust the learning speed and understanding of students to help them independently achieve their learning goals. This is done by designing modules that raise contextual issues, discovering geometric transformation concepts by developing their visual abilities with the display of colored modules, especially on graphics and illustrative drawings, and module usage rules that ensure students must complete previous activities to do the next activity.

\section{THE RESEARCH METHODS}

This research is a research and development ( $R$ \& D) research with the ADDIE development model which consists of 5 stages, namely: analysis, design, development, implementation, and evaluation. The research was carried out to produce certain products, and test the effectiveness of the product (Sugiyono: 2011). The product produced in this study is a 
module on geometric transformation material for high school students which was tested on 10 students of the tenth grade of high school. The design of the research method can be seen in Figure 1.

Figure 1.The Design of Research Methods

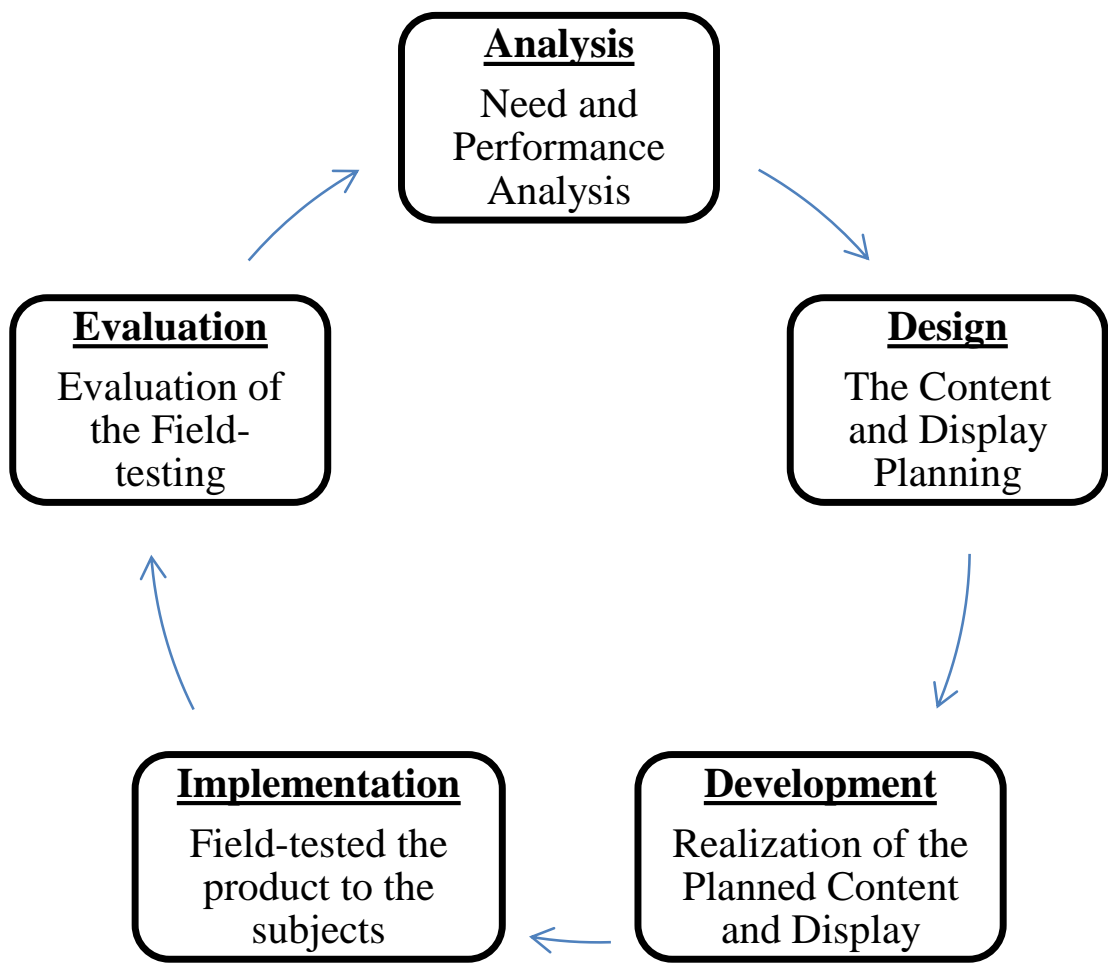

The techniques of data collection were validation sheets, media practical sheets, and test sheets. The validation sheet was used to measure MOSIRI validity both in terms of media and in terms of material. MOSIRI is declared valid if it is able to obtain an average score of validity $\geq 3$ which belongs to the fairly good category. The Media Practical Sheet was used to measure whether MOSIRI is practical for use by high school students. MOSIRI is stated to be practical if the majority of indicators on student practical sheets are considered appropriate (practical). Test Sheetwas used to measure whether the use of MOSIRI is effective for high school students. MOSIRI is declared effective if, after the implementation, an increase in student learning outcomes can be seen from the score of pretest and posttesttested using paired sample test.

\section{THE RESULTS OF THE RESEARCH AND THE DISCUSSION}

Development of MOSIRI (Geometry Transformation Module) for high school students was done using the ADDIE model consisting of analysis, design, development, implementation, and evaluation. These stages were carried out sequentially and systematically to create valid geometry transformation modules. The following is a description of the 5 stages of ADDIE that have been carried out:

\section{Analysis}

Development of Geometry Transformation Module (MOSIRI) for high school students was done through the analysis stages which were divided into needs analysis and performance 
analysis. The needs analysis stage revealed that there was a need for a module that can help high school students understand the concepts that exist in geometric transformation material. The module needed was not only a module that can help high school students understand geometric transformation material but also a module that was able to consider user comfort, can be used independently, not tied to other learning media, adaptive, and able to develop visual imagination to understand the concepts of transformationgeometry. The results of the performance analysis were that in the 2013 curriculum, the students needed teaching materials that can be used independentlywhere they are required to play an active role in achieving the set learning goals. Therefore, high school students are expected to be able to master the concepts that exist in geometric transformation material independently.

\section{Design}

The next stage did after the analysis stagewas the design stage. The design stagewas done by designing teaching materials in the form of a modulethat can be used independently on geometric transformation material for high school students so that they can re-learn thesubsections that have not been understood and are able to continue to the next sub-sections after completing the previous one. The module design consists of a cover design that reflects the contents of the module, the design of the borders section on the material, and the design of the module parts.

The sub-sectionsborder design was done by distinguishing the colors in each sub-section of the material. Green is used for translation material, red is used for reflective material, blue is used for rotational material, and purple is used for dilatation material. In addition, MOSIRI uses yellow for the competency test borders. Color differentiation is used to make it easier for the students to find the sub-sections they want to find and help them group the material in the module.

The design of the module parts was done by creating a design that allows the students to use the module as their teaching material independently. The components that exist as a result of the design of the module parts were theillustration, finding concepts in each sub-section in the material of geometry transformation, Let's Conclude, Let's Try, Let's Practice, and Competency Test. The illustration was used to provoke students' thinking to understand the concept of geometric transformation by using contextual problems. Finding concepts was done by providing a Cartesian diagram that helps students understand and find formulas from geometric transformations. The let's conclude section was used to help students conclude what they found from the activity of finding concepts through a Cartesian diagram. Let's try section was used to help students understand geometrical transformation material through examples of problems which solutions were presented with instructions on each step and involve students in completing it. Lets practice section was used as a means of practicing the geometry transformation problems. Competency test was used to measure the students' understanding of overall geometry transformation material. Lets practice section and competency testwere equipped with blank sheets where students could write their work results and answer keys so students can match their answers independently.

In addition, in designing the module, it was also considered the type and size of paper used and also the binding. The type of paper used is HVS by considering the comfort of students in using a colorful module. The size of the paper used is B5 by considering the practicality and 


\section{$\mathbf{a} \int \rho \mu$}

Al-Jabar: Jurnal Pendidikan Matematika

Vol. 9, No. 2, 2018, Hal 121 - 134

ease of the module to be carried out as well as to distinguish modules from notebooks, worksheets, and package books. The binding used is staples and glue binding. Staples are usedso that the binding on the module could last longer, while the glue binding is used after the module has been stapled to beautify the appearance of the module so that it is attractive enough to be used.

\section{Development}

After the module design had been finished, the actual module was developed. This development stage is the stage for creating module teaching materials based on the designs that had been made. The important thing to do is to create a module cover page that reflects the contents of the module while being able to attract students to use it. The cover page can be seen in Figure 2.
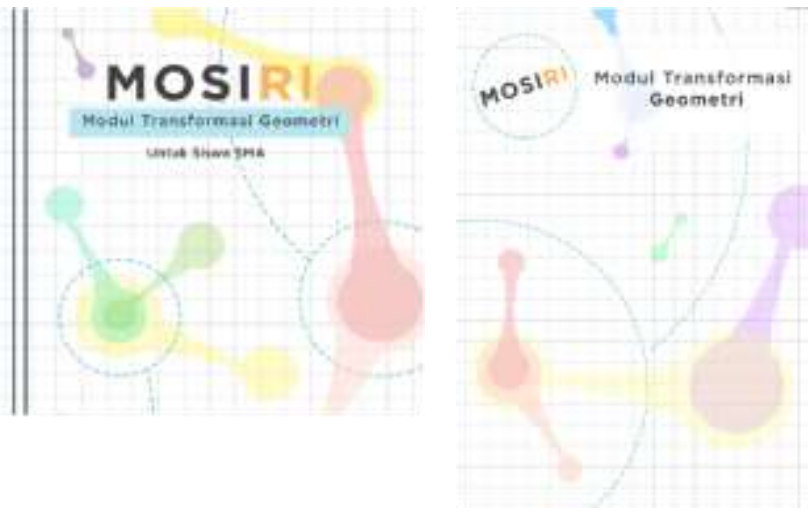

\section{Figure 2. TheCover Page}

The module is equipped with the rules for of usage, the objectives, and the benefits to be achieved through the module. The rules of usage are used to provide instructions for use and regulate how the students should work on the module so that it can be used independently. The inclusion of goals and benefits for the students to know what benefits can be obtained and what goals they will achieve after using the module. The appearance of rules of usage, objectives, and benefits can be seen in Figure 3.

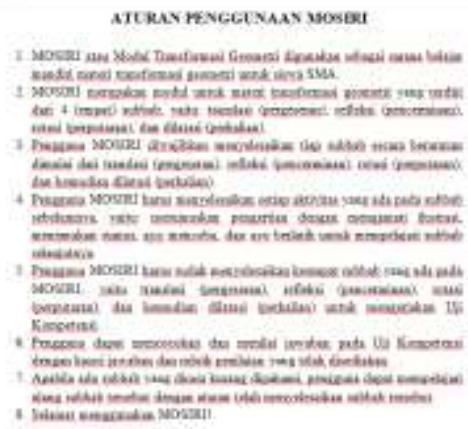

Trasdarustant

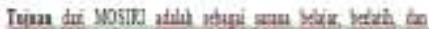

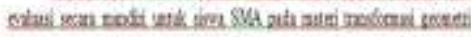

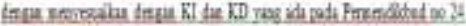

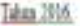

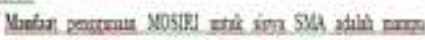

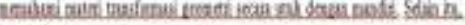

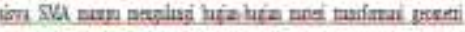
sutsachido boter.

Figure 3. Rules of Usage, Objectives, and Benefits

Each sub-section in the module is given colored-borders to make it easier for students to find and distinguish sub-sections in geometry transformation material. The borders display can be seen in Figure 4, Figure 5, Figure 6, and Figure 7. 


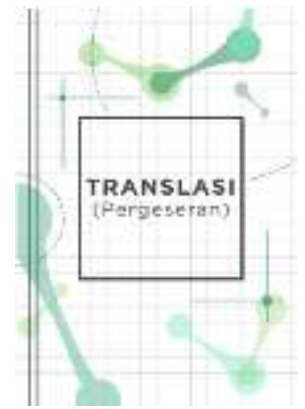

Figure 4. The Border for Translation

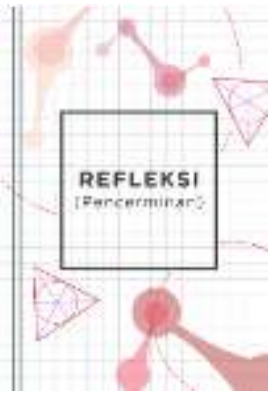

Figure 5. The

Border for

Reflection

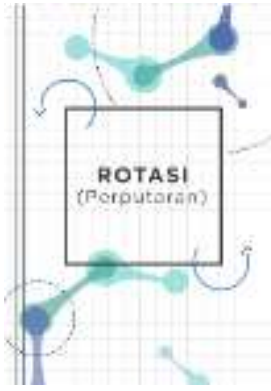

Figure 6. The

Border for

Rotation

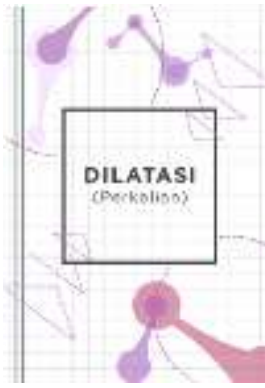

Figure 7. The

Border for

Dilation

In addition,each sub-section is equipped with various components, namely illustration; find concepts through Cartesian diagrams, Let's Conclude, Let's Try, and Let's Practice. The display of the components in each sub-section can be seen in Figure 8, Figure 9, Figure 10, Figure 11, and Figure 12 below:

\section{GRAKSঢASI} (PERGESERAM)

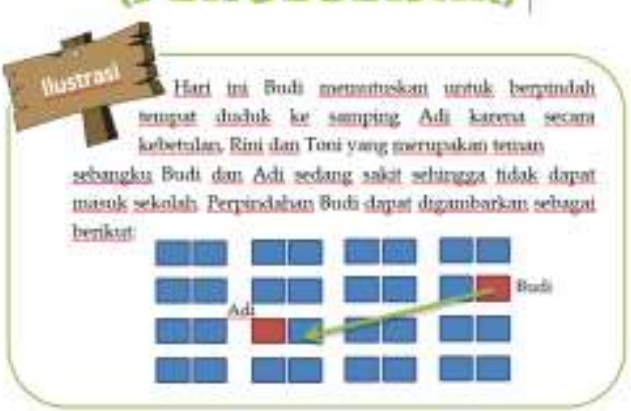

Figure 8. Illustration

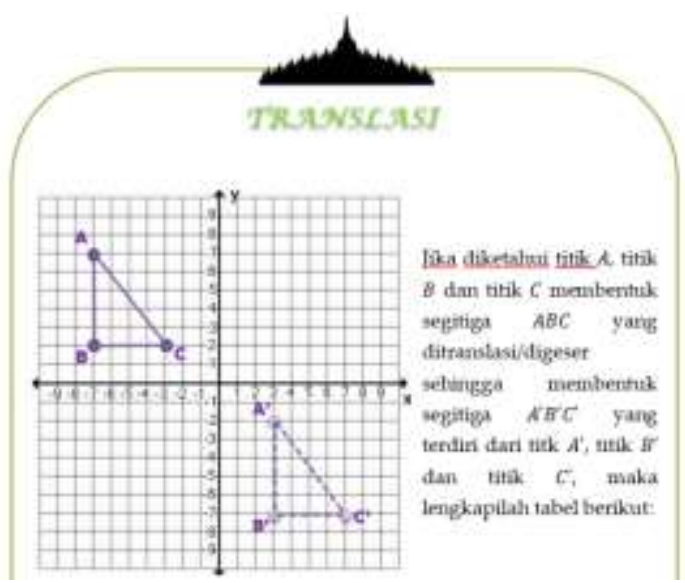

\begin{tabular}{|c|c|c|c|c|}
\hline Titik & $\begin{array}{l}\text { Koordinat } \\
\text { Awal }\end{array}$ & & $\begin{array}{l}\text { Matriks } \\
\text { Penambuh }\end{array}$ & $\begin{array}{l}\text { Koordinat } \\
\text { Akhir } \\
\text { (Pergeseran) }\end{array}$ \\
\hline A & $\left(\begin{array}{r}-7 \\
7\end{array}\right)$ & * & $\left(\begin{array}{c}10 \\
-9\end{array}\right)$ & $\left(\begin{array}{r}3 \\
-2\end{array}\right)$ \\
\hline B & ( ) & + & $(\quad)$ & ( ) \\
\hline \multirow[t]{3}{*}{ c } & ( ) & • & ( ) & ( ) \\
\hline & : & & : & : \\
\hline & $\left(\begin{array}{l}x \\
y\end{array}\right)$ & 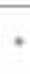 & ( ) & $\left(\begin{array}{l}x^{\prime} \\
y^{\prime}\end{array}\right)$ \\
\hline
\end{tabular}

Figure 9. ConceptFinding 
Dari informasi yang kalian dapatkan pada diagram kartesius dan kegiatanmelengkapi tabel, apabila $(x, y)$ merupakan koordinat awal dan ( $\left.x^{\prime}, y^{\prime}\right)$ merupakan koordinat akhir (pergeseran), maka dapat disimpulkan rumus translasi adalah:

$$
\left(\begin{array}{l}
x^{\prime} \\
y^{\prime}
\end{array}\right)=\left(\begin{array}{l}
a \\
b
\end{array}\right)+\left(\begin{array}{l}
x \\
y
\end{array}\right)=\left(\begin{array}{l}
a+x \\
b+y
\end{array}\right)
$$

Figure 10. Let's Conclude

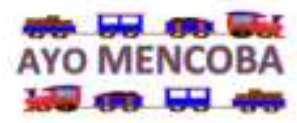

1. Titik $A(-6,2)$ digeser sejauh $T(5,8)$, maka letak titik $A^{\prime}$ adalah...

Penyelesaian:

Koordinat awal: $\left(\begin{array}{r}-6 \\ 2\end{array}\right)$

Digeser sejauh $\mathrm{I}(5,8)$ :

$\left(\begin{array}{l}x^{\prime} \\ y^{\prime}\end{array}\right)=(\quad)+\left(\begin{array}{l}x \\ y\end{array}\right)$

$\left(\begin{array}{l}x^{\prime} \\ y^{\prime}\end{array}\right)=\left(\begin{array}{l}5 \\ \end{array}\right)+\left(\begin{array}{l}2\end{array}\right)$

$\left(\begin{array}{l}x^{\prime} \\ y^{\prime}\end{array}\right)=(\quad)$

Jadi letak titik $A^{\prime}$ adalah $A^{\prime}(-1,10)$

Figure 11. Let's Try

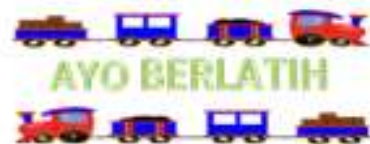

1. Bayangan titik $(3,-7)$ oleh translasi $(4,2)$ adalah.. Jawab: $(7,-5)$

2. Bayangan titik $A(2,3)$ oleh translasi $(2,7)$, kemudian dilanjutkan oleh translasi $(-6,-5)$ adalah...

Jawab: $A^{\prime}(-2,5)$

3. Tentukan bayangan lingkaran $(x-3)^{2}+(y+1)^{2}=4$ jika ditranslasikan $T=\left(\begin{array}{c}-5 \\ 2\end{array}\right)$ !

Jawab: $\left(x^{\prime}-2\right)^{2}+\left(b^{\prime}-1\right)^{2}=4$

Figure 12. Let'sPractice 
The module isalso equipped with competency tests used to measure the students' overall abilities in geometric transformation material. The competency test display can be seen in Figure 13.

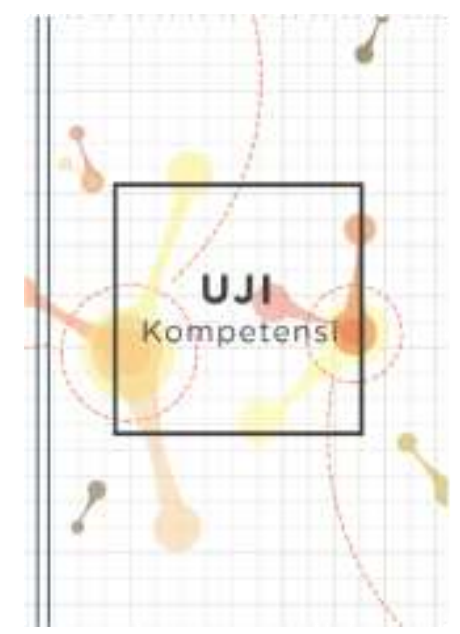

Figure 13. Competency Test

In addition, on each let's practice and the competency test section, an answer sheet is provided that can be used by students to write down the answer. The display of the answer sheet can be seen in Figure 14.

Figure 14. MOSIRI Answer Sheet

Before being tested, this media was tested by thevalidators consisted of material expert and media expert. The validator for the material expert was a lecturer in mathematics education, namely Mr. Tri Nova HastiYunianta, M.Pd. Material experts provided an assessment that can be seen in Table 1.

Table 1. Results of Validation by Experts Material

\begin{tabular}{lcc}
\hline \multicolumn{1}{c}{ Assessed Criteria } & Assessment & Category \\
\hline 1. ContentAspects & & Adequate \\
\hline $\begin{array}{l}\text { Media suitability with the material } \\
\begin{array}{l}\text { Completeness of material available on the } \\
\text { media }\end{array}\end{array}$ & 3 & Fairly adequate
\end{tabular}


Suitability of images and graphics displayed with the material

Clarity of pictures and graphics in containing problems related to material
4
Adequate
4
Adequate

\begin{tabular}{lcc}
\hline 2. language Aspects & & \\
\hline Ease of language to understand & 4 & Adequate \\
Sentence effectiveness & 3 & Fairly Adequate \\
Completeness of information in a sentence & 4 & Adequate \\
\hline Average Validity Score & 3.7 & VALID \\
\hline
\end{tabular}

Based on Table 1, it can be seen that the average validity score obtained is 3.7 . The score shows that learning media is valid in terms of material.

In addition to the material expert, there was also a media expert who is a mathematics lecturer named Dr. HariKristiyanto, M.Pd. The media expert provided validity score averages in terms of media. The score shows that learning media is valid. Media expert provided an assessment that can be seen in Table 2 .

Table 2. Results of Validation by Media Experts

\begin{tabular}{lll}
\hline \multicolumn{1}{c}{ Assessed Criteria } & Assessment & Categories \\
\hline 1. DisplayAspect & & \\
\hline Color suitability & 4 & Adequate \\
\hline Graphs and images attractiveness & 4 & Adequate \\
\hline Graphic, image, and font size suitability & 4 & Adequate \\
\hline $\begin{array}{l}\text { Media suitability with the characteristics of high } \\
\text { school students }\end{array}$ & 4 & Adequate \\
\hline 2. Writing Aspects & & \\
\hline Ease of writing to read & 4 & Adequate \\
\hline Ease of sentence to understand & 4 & Adequate \\
\hline Suitability of colors used & 4 & Adequate \\
\hline Average Validity Score & $\mathbf{4}$ & VALID \\
\hline
\end{tabular}

Average results of validation from the material expert in table 1 and the media expert in table 2 show that the media has fulfilled all validity indicators and it can be concluded that MOSIRI (Geometry Transformation Module) for high school students is valid.The material expert assessed the suitability of the stepsto be used by high school students. The media expert considers that this media is interesting and suitable for learning. These results are similar to the results of research conducted by Susilo (2016), Rizqi, Parmin, \&Nurhayati, (2013), Mardati (2017), Lasmiyati (2014) and TabahSubekti, ElaMinchahLailaAlawiyah (2016) which shows that the module is valid and suitable for learning.

\section{Implementation}

MOSIRI for high school students was tested on 10 high school students of class $\mathrm{X}$ who have studied matrices and have not studied geometry transformation material yet. The module was tested by asking the students to complete each activity in the module independently, both in terms of the process and the process time. Students were allowed to repeat difficult parts to 
understand or to move on to other parts after completing the previous section. Although the students were given independent time to work on the module, in this study, the researchersheld regular meetings with the subjects to see the process and to discuss the extent the usage of the module and the difficulties experienced by students which will later be included in suggestions for further module development research.

\section{Evaluation}

The researchers administered the pretest to the subjects to see how far was the students' understanding of geometry transformation material. Then the researcher asked the subjects to do the learning independently by using a module. After they have finished using the module, the researchers gave the posttest to the subjects. The significance of the pretest and posttest resultsis shown in Table 3.

Table 3.The Score ofPretest and Posttest

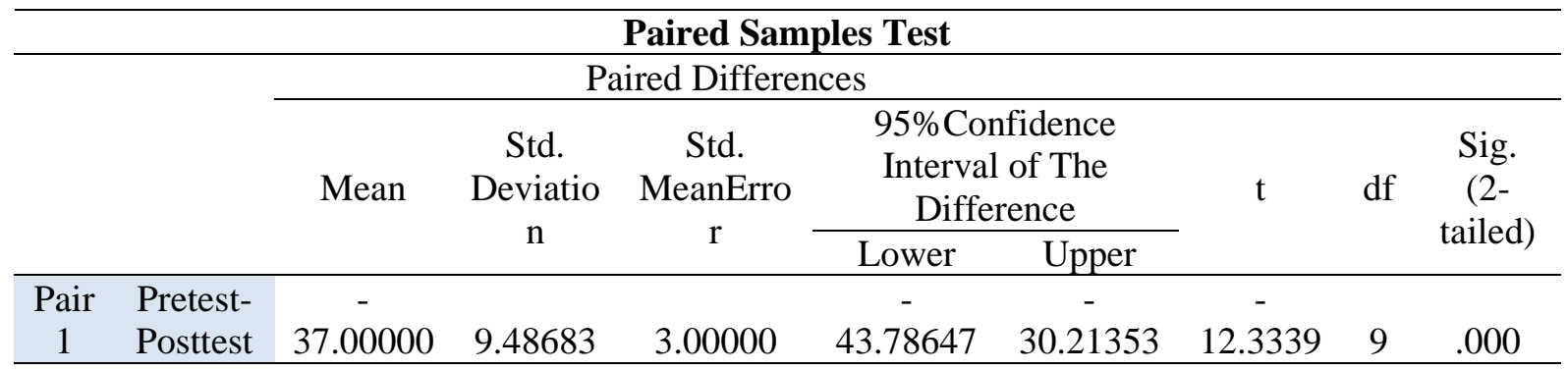

The data of pretest and posttest have been declared normally distributed with significance more than 0.05 , then the mean differencepaired sample test was conducted. Based on Table 3, it can be seen that thesignificance of thepretest-posttest is $0,000(0,000 \leq 0.05)$ which means that there is a difference or increase between the score of the pretest and posttest. Apart from the significance value, the increase in student score can be seen from the average results of the pretest and posttest. The average score of pretest and posttest can be seen in Table 4.

Table 4. Average Score ofPretest and Posttest

\begin{tabular}{lr|r}
\hline \multicolumn{3}{c}{ Report } \\
\hline & Pretest & Posttest \\
\hline Mean & 88.0000 & 51.0000 \\
\hline $\mathrm{N}$ & 10 & 10 \\
\hline Std. Deviation & 9.94429 & 7.14920 \\
\hline
\end{tabular}

Based on Table 4, it can be seen that the average score of the pretest is 51 and the average score of the posttest is 88 . The average score indicates that the score of the pretest is still below the minimum standard which is $\geq 75$. After the module was introduced, subjects were asked to do the posttest and improve their learning outcomes with the averagescore of posttest above the minimum standard which isalso $\geq 75$. Seeing the score improvement experienced by students after the application of the module in Table 3 and Table 4, it can be concluded that MOSIRI is effective to be used to improve students' learning outcomes. This result is supported byNasution (2016), Khayati et al. (2016) and Tjiptiany\&Muksar (2016) which shows that the module is able to improve students' mathematics learning outcomes effectively, as well as the results of 
research by Utaminingsih (2017) which shows that the module is able to be used to support learning.

After the subjects have applied the module in learning, the subjects were asked to make an assessment of the module by using the media practicality sheet. The assessment results can be seen intable 5 .

Table 5. Summary of the Media Practicality Sheet

\begin{tabular}{cccccccc}
\hline \multirow{2}{*}{ Subject } & \multicolumn{8}{c}{ Indicators } \\
& $\mathbf{1}$ & $\mathbf{2}$ & $\mathbf{3}$ & $\mathbf{4}$ & $\mathbf{5}$ & $\mathbf{6}$ & $\mathbf{7}$ \\
\hline $\mathbf{1}$ & $\mathrm{P}$ & $\mathrm{P}$ & $\mathrm{P}$ & $\mathrm{P}$ & $\mathrm{P}$ & $\mathrm{P}$ & $\mathrm{P}$ \\
$\mathbf{2}$ & $\mathrm{P}$ & $\mathrm{P}$ & $\mathrm{P}$ & $\mathrm{TP}$ & $\mathrm{P}$ & $\mathrm{P}$ & $\mathrm{P}$ \\
$\mathbf{3}$ & $\mathrm{P}$ & $\mathrm{P}$ & $\mathrm{TP}$ & $\mathrm{P}$ & $\mathrm{P}$ & $\mathrm{P}$ & $\mathrm{P}$ \\
$\mathbf{4}$ & $\mathrm{P}$ & $\mathrm{P}$ & $\mathrm{P}$ & $\mathrm{P}$ & $\mathrm{P}$ & $\mathrm{P}$ & $\mathrm{P}$ \\
$\mathbf{5}$ & $\mathrm{P}$ & $\mathrm{P}$ & $\mathrm{TP}$ & $\mathrm{P}$ & $\mathrm{P}$ & $\mathrm{P}$ & $\mathrm{P}$ \\
$\mathbf{6}$ & $\mathrm{P}$ & $\mathrm{P}$ & $\mathrm{P}$ & $\mathrm{P}$ & $\mathrm{P}$ & $\mathrm{P}$ & $\mathrm{P}$ \\
$\mathbf{7}$ & $\mathrm{P}$ & $\mathrm{P}$ & $\mathrm{P}$ & $\mathrm{TP}$ & $\mathrm{P}$ & $\mathrm{P}$ & $\mathrm{P}$ \\
$\mathbf{8}$ & $\mathrm{P}$ & $\mathrm{P}$ & $\mathrm{P}$ & $\mathrm{P}$ & $\mathrm{P}$ & $\mathrm{P}$ & $\mathrm{P}$ \\
$\mathbf{9}$ & $\mathrm{P}$ & $\mathrm{P}$ & $\mathrm{TP}$ & $\mathrm{TP}$ & $\mathrm{P}$ & $\mathrm{P}$ & $\mathrm{P}$ \\
$\mathbf{1 0}$ & $\mathrm{P}$ & $\mathrm{P}$ & $\mathrm{TP}$ & $\mathrm{P}$ & $\mathrm{P}$ & $\mathrm{P}$ & $\mathrm{P}$ \\
\hline
\end{tabular}

Based on Table 4, the indicator points 1, 2, 5, 6, and 7 as many as 10 subjects declare that the media is practically expressed through the indicators. The material on media is clear and complete, clear and complete rules of usage, not bound by other media, and easy to use.

On point 3 of the indicators, 6 subjects stated the media was practical while 4 other subjects stated that this media is impractical. It can be concluded that this media is practical and can be used at any time. On point 4 of the indicator, 7 subjects stated that this media is practical while 3 other subjects stated that this media is impractical. It can be concluded that this media is practical and can be used anywhere. Overall, MOSIRI is stated to be practical so that it is feasible to use. The result is supported by Windarti's (2015) research which shows that the module is practical to be used and also supports the research results of Wijayanti (2005), Mulyono (2014), and Fitri, Kurniawan \& Ngazizah 2013) which shows that the module is feasible to use.

\section{CONCLUSION AND SUGGESTION}

This media is a module on geometric transformation material for high school students which is declared valid from material aspects and media aspects with an average score of the validity of 3.7 (valid) and in terms of media of 4 (valid). This module was tested on 10 high school students of class $\mathrm{X}$ and is declared practical based on the majority answerson the indicators of the media practicality sheet. In addition, with the help of a test sheet, it can be seen that this module is able to improve learning outcomes. This can be seen from the results of a paired simple test which shows a significance value of $0,000(\leq 0,05)$ which means that this module is able to provide differences or improve student learning outcomes from the average pretest score of 51 to theaverage posttest score of 88 . Based on the three tests, this module is 
declared valid, practical, and effective to be used in geometric transformation material for high school students. This module is able to be used to help the students to achieve their learning goals independently.

The researchers suggest conducting a field-testing with a larger number of subjects in the next study to see the practicality and effectiveness of the module. In addition, it is recommended to develop the modules into electronic formso that it could be more practical, effective, and adaptive for high school students.

\section{REFERENCES}

Albab, U.I., Hartono,Y., Darmawijoyo 2014. "Kemajuan Belajar Siswa pada Geometri Transformasi Menggunakan Aktivitas Refleksi Geometri”. Cakrawala Pendidikan, 3, 338-340.

Elinda., Nuryana. (2013). Pengaruh Penggunaan Modul terhadap Hasil Belajar Siswa pada Mata Pelajaran Matematika Kelas VII Sekolah Menengah Pertama (SMP) Negeri 8 Kota Cirebon. Eduma, 2(1),

Fitri, L. A., Kurniawan, E. S., \& Ngazizah, N. (2013). Pengembangan Modul Fisika pada Pokok Bahasan Listrik Dinamis Berbasis Domain Pengetahuan Sains untuk Mengoptimalkan Minds-On Siswa SMA Negeri 2 Purworejo Kelas X Tahun Pelajaran 2012/2013. Jurnal Radiasi, 3(1), 19-23.

Hollebrands, K. F. (2003). High School Students's Understanding of Geometric Transformations in the Context of a Technological Environment. Journal of Mathematical Behavior, 22(1), 55-72.

Khayati, Sujadi, Saputro. (2016). Pengembangan Modul Matematika untuk Pembelajaran Berbasis Masalah (Problem Based Learning) pada Materi Pokok Persamaan Garis Lurus Kelas VIII Sekolah Menengah Pertama (SMP). Jurnal Elektronik Pembelajaran Matematika, 4(7), 608-621.

Khoirotunnafi'ah, L. (2017). Pengembangan Modul Pembelajaran Matematika Berbasis Aktivitas Kritis Yang Bernuansa Islami Pada Materi Transformasi. (Doctoral dissertation, Universitas Islam Negeri (UIN) Sunan Ampel Surabaya).

Lasmiyati, I. H. (2014). Pengembangan Modul Pembelajaran untuk Meningkatkan Pemahaman Konsep dan Minat Sekolah Menengah Utama (SMP). Pythagoras: Pendidikan Matematika, 9(2), 161-174.

Nasution, A. (2016). Pengembangan Modul Matematika Berbasis Masalah untuk Meningkatkan Kemampuan Pemecahan Masalah Matematika Siswa. Jurnal Rekognisi, 1(1), 47-63.

Mardati. (2017). Pengembangan Modul Matematika dengan Pendekatan Kontekstual pada Materi Bangun Datar untuk Mahasiswa PGSD UAD. Jurnal JPSD (Jurnal Pendidikan Sekolah Dasar), 3(2), 1-7.. 
Marpaung, Y. (2002). Pendidikan Matematika Realistik Indonesia Perubahan Paradigma dalam Pembelajaran Matematika di Sekolah. Universitas Negeri Malang: Prosiding Konfrensi Nasional Matematika XI.

Mulyono, S., Hasyim, A., \& Sutiraso, S. (2014). Pengembangan Bahan Ajar Modul Matematika. Jurnal Teknologi Informasi Komunikasi Pendidikan (Old), 2(3).

Paradesa, R. (2016). Pengembangan Bahan Ajar Geometri Transformasi Berbasis Visual. Jurnal Pendidikan Matematika JPM RAFA, 2(1), 56-84.

Permendikbud Nomor 24 Tahun 2016, Tentang Standar KI dan KD.

Permendiknas Nomor 41 Tahun 2007, Tentang Standar Proses.

Rizqi, A. M., Parmin, \& Nurhayati, S. (2013). Pengembangan Modul Ilmu Pengetahuan Alam (IPA) Terpadu berkarakter Tema Pemanasan Global untuk Siswa Sekolah Menengah Pertama (SMP)/Madrasah Tsanawiyah (MTs). Unnes Science Education Journal, 2(1), 203-208.

Ruseffendi, E.T. (2005). Dasar-dasar Penelitian Pendidikan dan Bidang Non-Eksakta Lainnya. Bandung : Tarsito.

Saputra, R., Falahudin, I., \& Testiana, G. (2016). Pengembangan Bahan Ajar Matematika Berbasis Komputer untuk Siswa Kelas VIII di SMP Negeri 19 Palembang. Jurnal Pendidikan Matematika JPM RAFA, 2(2), 249-268.

Setiawan, B., \& Wanarti R, P. (2009). Pengembangan Modul Pembelajaran Plc Pada Standar Kompetensi Memprogram Peralatan Sistem Kendali Elektronik Dengan I/O Berbantuan Plc Dan Komputer Di Smk Negeri 2 Lamongan. Jurnal Pendidikan Teknik Elektro, 3(3), 425-431

Subekti, T. (2016). Pengembangan Modul Bahasa Indonesia Bermuatan Nilai Karakter Kebangsaan Bagi Mahasiswa Pendidikan Guru Sekolah Dasar (PGSD). Profesi Pendidikan Dasar, 3(2), 92-101..

Susilo, A. (2016). Proses Pembelajaran Akuntansi Siswa Kelas Xii Sma N I Slogohimo 2014, 26(1).

Tjiptiany, E. N., \& Muksar, M. (2016). Pengembangan Modul Pembelajaran Untuk Membantu Siswa Sma Kelas X Dalam Memahami Materi Peluang. Jurnal Pendidikan, 1(10), 1938-1942.

Utaminingsih, Carina D.T., Wasitohadi. (2017). Pengembangan Modul Pembelajaran Matematika dengan Menerapkan Pendekatan Saintifik dalam Materi Pecahan untuk Kelas 5 SD. E-jurnalmitrapendidikan, 1(4), 408-419.

Wijayanti, W. (2005). Pengembangan Modul Matematika berbasis Model Pembelajaran CTL (Contextual Teaching and Learning) dilengkapi dengan AA (Authentic Assessment) Berbantuan Flipbook Maker. AKSIOMA: Jurnal Matematika dan Pendidikan Matematika, 7(2), 79-91.. 


\section{$\mathbf{a} \int \rho \mu$ \\ 1SSN $2086-5872$
$e^{-1}-155 N$
$2540-7562$}

Al-Jabar: Jurnal Pendidikan Matematika

Vol. 9, No. 2, 2018, Hal $121-134$

Windarti. (2015). Pengembangan Modul Pembelajaran Logika yang Memuat Pendidikan Karakter untuk Siswa Kelas X Sekolah Menengah Kejuruan (SMK). Phytagoras: Jurnal Pendidikan Matematika, 10(1), 106-116. 